\title{
PRVNÍ KOMPLEXNÍ NÁRODOHOSPODÁŘSKÉ HODNOCENÍ PROCESU PRIVATIZACE V ČESKÉ REPUBLICE
}

\section{Pavla Chmelová*}

\section{Karel Zeman: Analýza privatizačního procesu v České republice}

Praha: Univerzita Karlova v Praze, Nakladatelství Karolinum, 2014. 1.vydání. 294 stran. ISBN: 978-80-246-2939-1.

Transformace $\mathrm{z}$ centrálně řízené ekonomiky na ekonomiku tržní byla v České republice započata před čtvrt stoletím. To je dostatečně dlouhá doba na provedení zevrubné analýzy této systémové změny při oproštění se od vědomých i neúmyslných desinterpretací tehdejších kroků reformátorů a tvůrců hospodářské politiky. S dostatečným časovým odstupem, kterým 25 let bezesporu je, se naskýtá ideální př́ležitost ohlédnout se za tímto v novodobé historii našeho státu doposud nejvýznamnějším národohospodářským počinem bez politického zabarvení a z pohledu ekonomického, vědeckého a zejména co možná nejvíce objektivního analyzovat a zhodnotit daný proces.

Zeman se ve své publikaci zaměřuje na privatizační proces jakožto významnou část čtvrtého pilíře transformace. Tento pilír spočívá ve změně vlastnických práv, a ačkoliv jej na rozdíl od prvních tř́ pilírư nelze ani v současné době považovat za zcela uzavřený, jeho stěžejní část, ve vyjádření počtu i objemu převodů, resp. prodejů, již realizována byla. Pro učinění adekvátních, daty podložených závěrů i pro současnou dobu platných a hodnotných doporučení tak nebyla vhodnější doba, jelikož při př́ilišném lpění na přistoupení k závěrečnému hodnocení až po zprivatizování poslední majetkové podstaty by mohlo dojít k oddalování potřebného výzkumu až do doby, kdy by sice byla k dispozici komplexnější data, ale zároveň bychom takový výzkum mohli zařadit spíše do kapitol hospodářských dějin. Což s sebou nese všechna související negativa, jako např́íklad omezenou dostupnost a výtěžnost primárních zdrojů či ztrátu potenciálu bezprostřední využitelnosti v soudobé praktické hospodářské politice. S ohledem na průběh církevních restitucí a držení strategických pozic státu v některých odvětvích by také k tomuto okamžiku nemuselo dojít nikdy.

Silnou potřebu analýzy předmětné oblasti, vnímanou společností po řadu let, potvrzují četnost a stálost diskusí i množství dosavadních příspěvků k danému tématu z per ekonomů, právníků i vykonavatelů státní moci. Ty však, s ohledem na jejich úzké zaměření a selektivní, možno říci i nahodilý přístup, nelze v žádném př́ípadě považovat za adekvátní analytický materiál k tolik potřebnému vyřknutí verdiktu ohledně správnosti nastavení privatizačních procesů. Takto definovaná výzva je tak stále aktuální, čehož si byl Zeman evidentně vědom a při využití teoretických ekonomických znalostí na straně jedné a praktických zkušeností, dokonce přímo z inkriminovaného procesu privatizace v roli státního manažera na straně druhé, přistoupil ke zpracování systematické analýzy

* Pavla Chmelová (chmelova.pavla@seznam.cz, xchmp12@vse.cz, Pavla.Chmelova@mfcr.cz), Vysoká škola ekonomická v Praze, Národohospodářská fakulta; Ministerstvo financí ČR, Odbor 19 Financování kapitol státního rozpočtu II, Oddělení Financování dopravy, průmyslu a místního rozvoje. 
privatizačního procesu v celé své komplexnosti. A již na tomto místě předesílám, že tento značně ambiciózní záměr je nutno v souhrnu považovat za úspěšně naplněný.

Ucelenost díla se přitom netýká jen metod privatizace a institucionálního zajištění, ale vyplývá i ze systematického a vícerozměrného analytického př́stupu, jenž je promítnut do samotného obsahu publikace. Text je strukturován do šesti hlavních kapitol. Ekonomické teorie, relevantní pro téma privatizace, jsou vymezeny v rámci první kapitoly, přičemž byly vesměs veškeré prokázány ve vztahu ke změně vlastnických práv jako platné. Nejvýrazněji Zeman akcentuje působení zájmových skupin, existenci jevu dobývání renty, celkově řadu př́padů více či méně závažných vládních selhání. V souvislosti se závěry analýz je pak čtenáři názorně demonstrován potenciální rozměr transakčních nákladů, které definoval Ronald Coase v 60. letech 20. století, vznikajících při realizaci hospodářské politiky.

Obsahem druhé a třetí kapitoly je výčet právních režimů a v jejich rámci fungujících institucí, z kterého je zřejmý rozměr zkoumané problematiky i jeho nutná složitost. Vedle samotného vymezení legislativního rámce pro převod majetku státu včetně úpravy vlastnických práv k zemědělskému majetku a půdě bylo nutné již v prvních letech po změně režimu přijmout i zákonné normy ustanovující zcela nové instituce $\mathrm{k}$ výkonu zmocnění v dané věci. V publikaci jsou přehledně uvedeny jednotlivé kompetentní orgány veřejné správy a definována jejich role $\mathrm{v}$ procesu malé privatizace, velké privatizace i privatizace zemědělského a lesnického majetku. Výlučně za účelem realizace čtvrtého transformačního pilíre vznikly Ministerstvo pro správu národního majetku a jeho privatizaci ČR a okresní privatizační komise, Fond národního majetku ČR a Pozemkový fond ČR. Ty doplnily již dříve existující Ministerstvo financí ČR, které disponovalo řídící působností vůči nově vzniklému Centru kupónové privatizace, RM systému a Středisku cenných papírů. V neposlední řadě doplňovaly rozsáhlou sít' transformačních subjektů ministerstva, jakožto zakladatelé státních podniků, státní podniky samotné a vláda ČR.

Na poznatcích z druhé a třetí kapitoly je vystavěna nejrozsáhlejší, ústřední čtvrtá kapitola, která analyzuje velmi detailním způsobem proces privatizace z pohledu použitých privatizačních metod ve všech možných kombinacích institucionálního zajištění a právního režimu. Prezentovaná datová „matice“ je poté velmi názorně sumarizována v kapitole páté, jejíž hlavním smyslem a výstupem jsou agregované číselné údaje za jednotlivé transformační instituce i celková kvantifikace privatizačních př́jmů a nákladů. V této části si tedy dovolím odchýlit se od originální posloupnosti výzkumu autora a před rozborem druhé části čtvrté kapitoly, která se věnuje vybraným klíčovým otázkám IV. transformačního pilíre, pojednám souborně o výstupech úzce souvisejících úvodních částí čtvrté kapitoly a kompletující kapitoly navazující.

Při hodnocení jednotlivých privatizačních metod klade Zeman důraz na faktor relevance vzniku dlužníků a konsekventně růst transakčních nákladů. $Z$ tohoto pohledu považuje za jednoznačně suboptimálně využívané veřejné dražby, které jsou v porovnání s jednokriteriálními veřejnými obchodními soutěžemi administrativně jednodušší a vyznačují se menšími transakčními náklady. Největší kritiku směřuje Zeman s určitostí k bezúplatným převodům majetku i akcií do vlastnictví obcí. V souvislosti s následným úplatným prodejem soukromým subjektům odhaduje neinkasovanou vysokou hodnotou majetku státem a tedy ztrátu pro státní rozpočet ,v řádu desítek, možná až stovek miliard korun “. Takto vymezené fiskální dopady předmětného vývoje by v relaci na svůj rozměr a váhu měly být kvantifikovány v navazujícím výzkumu. $Z$ analýzy rozpočtové politiky 
obcí, při zohlednění podílu těchto dodatečných privatizačních př́ijmů, by byla zjištěna míra prohospodaření daných prostředků.

$\mathrm{Na}$ bezúplatný převod obcím lze nahlížet kriticky i $\mathrm{v}$ souvislosti se ztrátou většinového podílu v některých, často velmi strategických podnicích. Podobně kritickým způsobem se Zeman vyjadřuje $\mathrm{k}$ institutu zlatých akcií. Zvláštní práva, která se $\mathrm{k}$ tomuto druhu akcií vážou, mají široký potenciál pro dlouhodobou ochranu státních zájmů spočívající v eliminaci spekulativních nákupů ze strany zahraničních investorů a měly být proto právně lépe ošetřeny a více využívány. Ve vazbě na tento závěr nicméně považuji za nutné upozornit i na druhou stranu mince, kdy s ohledem na významný rozsah strategických práv spojených s vlastnictvím těchto prioritních akcií považuji za oprávněné se domnívat, že s rozšířením jejich počtu či dobou platnosti by došlo v konečném důsledku k poklesu inkasa kupní ceny zbylých cenných papírů privatizovaného podniku, což je $\mathrm{z}$ určitého hlediska také jev negativní.

Publikace se nevyhýbá ani často diskutované kupónové privatizaci. Za její pozitiva jsou jmenovány umožnění účasti každé fyzické osobě, zprivatizování značné části ostatními metodami těžko udatelného majetku a nemožnost vzniku dlužníků. Jako negativní jsou vnímány problematický a nejasný výběr nabyvatelů akcií při převisu poptávky a nesystémový výběr podniků, kdy byly do tohoto režimu zbytečně zařazovány atraktivní podniky namísto podniků s vysokou účetní avšak nízkou tržní hodnotou. Zeman se dotýká i tématu činnosti investičních fondů, které významným způsobem poškodily nemalou část drobných držitelů akcií získaných v rámci kupónové privatizace. Nepopírá výrazné negativní dopady vyplývající z nedokonalého právního rámce, apeluje však na odpoutání se od dogmatického vnímání př́mého kauzálního vztahu mezi nekalými praktikami a samotnou privatizační metodou.

Druhá část čtvrté kapitoly se zaměřuje na vybrané stěžejní problémy celého procesu. V části bilancující celkové výnosy a náklady spojené s privatizačním procesem českých bank dochází Zeman k alarmujícímu výpočtu finanční ztráty ve výši 235 mld. Kč. Neefektivnost prodeje privatizovaných bank s údajnou převahou nebonitních aktiv a bez potenciálu ziskovosti vyplynula z provedené analýzy vývoje jejich ekonomické kondice. Tento silný závěr přitom vychází z celého souboru determinujících faktorů. Negativně působily počáteční nesprávný odhad hodnoty majetku, nestrategický prodej většinového podílu akcií či jeho ztráta způsobená nenavyšováním základního jmění či neefektivní výkon akcionářských práv. Za důkaz čistě tržní povahy lze považovat vývoj ekonomických parametrů po dokončení procesu, kdy byl de facto okamžitě využit potenciál předmětných bankovních institucí a hospodářské výsledky se bez kapitálového posílení, pouze důsledným manažerským řízením, začaly rapidně zlepšovat.

Významných výstupů dosahuje Zeman také v kapitole pojednávající o řízení procesu vymáhání pohledávek po lhůtě splatnosti vzniklých v rámci IV. transformačního pilíře. Nadstavbou zhodnocení bývalého stavu, hodnou ocenění, je praktická aplikovatelnost úspěšného modelu v současném systému vymáhání nedobytných pohledávek. Což implikuje při výši 123 mld. Kč jen daňových a celních nedoplatků v roce 2014 možnost dosažení přebytkového ročního rozpočtu. Nutné je nicméně upozornit na méně znatelný pozitivistický přístup u demonstrativního příkladu Fondu národního majetku, což je částečně dáno obtížnější dosažitelností relevantních dat. Pokus o sestavení a podrobnější analýzu časových řad by však celou záležitost osvětlil, zvláště ve vztahu k nálezu Nejvyššího kontrolního úr̆adu ČR z kontrolní akce č. 02/30 z roku 2003, kterým bylo konstatováno 
nedostatečné využívání všech dostupných zákonných nástrojů při uzavírání smluv, kdy ke konci roku 2001 evidoval Fond pohledávky po lhůtě splatnosti ve výši téměř 8 mld. Kč, tj. $57 \%$ hodnoty všech v jeho účetnictví vedených pohledávek.

$\mathrm{V}$ neposlední řadě, ve shodě $\mathrm{s}$ autorem akcentuji národohospodářský význam privatizačního procesu. Ten $\mathrm{z}$ pohledu dopadů na veřejné rozpočty vyplývá $\mathrm{z}$ několika zjištění. $Z$ analýzy je zřejmé, že objem prostředků získaný v souhrnu ze všech privatizačních metod byl nebývalý, přičemž skrytý potenciál pro inkaso př́imů byl ještě vyšší. To je úzké pojetí, týkající se pouze př́jmové strany, konsekvence průběhu celého procesu a ještě překvapující výsledky, v negativním slova smyslu, vykrystalizovaly při analýze reálného využití těchto disponibilních zdrojů. Př́ijmy byly prohospodařeny neadekvátním způsobem, kdy namísto prioritních národních zájmů byly alokovány na potřeby běžného typu, resp. na krytí deficitů státního rozpočtu, financování položek „politicky atraktivních“ apod. Nyní se proto nacházíme v situaci, kdy není dobudována páteřní sít' dopravní infrastruktury ani provedena důchodová či zdravotní reforma. Nad rámec hodnocení obsažené v publikaci je nutno považovat situaci za ještě závažnější, jelikož nejenže nebyly $\mathrm{k}$ dosažení těchto klíčových cílů hospodářské politiky využity př́ijmy z privatizace, v rozporu s původním záměrem, ale pomalu čelíme i ztrátě finančních zdrojů z Evropské unie. Přičemž v př́ípadě dopravní infrastruktury může být Česko na národní zdroje odkázáno dř́ve než $\mathrm{s}$ koncem současného programového období a faktickým překlasifikováním České republiky z př́ijemce na přispívající členský stát a ve větší míré. Důvodem jsou problémy s legislativními změnami upravujícími proces EIA, kdy při nutnosti opakování celého procesu dle současně platného práva by se jednalo o výrazné zpoždění v př́ípravě i realizaci předmětných akcí, což by vyústilo v reálnou nemožnost čerpání peněz z evropských operačních programů.

Při uvědomění si celého spektra národohospodářských dopadů se nabízí rozpracování časových řad demonstrovaných $\mathrm{v}$ publikaci ve vazbě na hospodářský a politický cyklus. Vhodné by bylo zacílit na hospodaření $\mathrm{s}$ privatizačními př́ijmy $\mathrm{v}$ jednotlivých letech dle bilančního výsledku státního rozpočtu v rozlišení jednotlivých vlád a při zohlednění výkonu ekonomiky. Tedy analyzovat vliv růstu HDP a vývoje př́ijmů z privatizačních účtů na dosaženou rozpočtovou bilanci, tzn. rozlišit její cyklickou a strukturální složku, definovat př́íspěvek privatizačních př́imů a obohatit tak odbornou diskuzi ohledně rozpočtové odpovědnosti a dodržování doktríny fiskální udržitelnosti v historii České republiky.

Meritem šesté kapitoly je identifikace pozitiv i negativ privatizačního procesu v České republice za celé sledované období, která uzavírá Zemanovo zcela jedinečné a komplexní pojetí analýzy privatizačního procesu v ČR. Lze shrnout, že v rámci publikace je komparací detailních dat i souhrnných položek, jejich analýzou i syntézou umožněno čtenáři vytvořit si naprosto reálný obraz o významu, dopadu a širších souvislostech českého privatizačního procesu. Jiní autoři se často $\mathrm{v}$ rámci limitů jednostranně zaměřené specializace zatím vždy věnovali otázce transformace $\mathrm{z}$ hlediska dílčí, úzce vymezené oblasti problému. Zemanova publikace naopak přináší originální a dřive nepublikované soubory dat za všechny transformační instituce, právní režimy a privatizační metody, přičemž se nejedná o pouhou datovou základnu (přestože i ta je ve své komplexnosti významnou přidanou hodnotou a původním vědeckým počinem), ale i o systémovou analýzu a syntézu celého privatizačního procesu v ČR.

Zeman kombinuje analýzy právního rámce, institucionálního zajištění, statistickou a makroekonomickou analýzu i syntézu celého privatizačního procesu. Výjimečnost knihy 
a její přidaná hodnota pro širší okruh čtenářů vyplývají také z kvalitně zpracované teoretické části a jejího provázání s výzkumnou částí, resp. potvrzení či vyvrácení ekonomické teorie $\mathrm{v}$ reálné praktické hospodářské politice. Tento prvek není $\mathrm{v}$ publikacích tohoto typu samozřejmostí, přestože teoretická a praktická stránka věci jsou ve většině př́ípadů, u ekonomických témat nevyjímaje, neoddělitelné nádoby.

Oproti dříějšsím, sporadicky se objevujícím textům věnujícím se výlučně kupónové privatizaci, popř. činnosti Ministerstva privatizace nebo Fondu národního majetku, podrobuje Zeman rozboru i zbývající privatizační metody a neopomíjí ani analýzu činnosti Pozemkového fondu ČR. Ten z pohledu absolutního počtu převodů privatizovaného majetku převyšuje se svými 830 tisíci převody výkon Fondu národního majetku přibližně pětadvacetkrát, a přesto se jeho činností doposud žádná výzkumná práce nezabývala. Celkové transakční náklady na proces změny vlastnictví ze státního na soukromé byly odhadnuty v gigantické výši činící více než půl bilionu korun.

Tuto publikaci je z výše uvedených důvodů nutno považovat za první a jedinečnou svého druhu. S množstvím shromážděných, analyzovaných a v jistém slova smyslu šokujících a překvapujících dat souvisí značné množství otázek a podnětů, které z práce vyplynuly, a kterými se otevírá široký prostor pro navazující vědecký výzkum. Zemanova publikace představuje zcela základní studnici dat a vědomostí pro autory budoucích tematicky blízkých a rozšiřujících textů. 